\title{
Marlena Grabowska*
}

\section{PERCEPCJA I MOTYWY PRZEDSIĘBIORCZOŚCI W POLSCE I W WYBRANYCH KRAJACH}

\section{WPROWADZENIE}

Zasadniczym celem opracowania jest teoretyczna i empiryczna analiza wybranych aspektów przedsiębiorczości. Istotność podjętego tematu wynika przede wszystkim z roli i wpływu działań przedsiębiorczych zarówno na ekonomiczną, jak i społeczną sferę funkcjonowania podmiotów. M. Bratnicki podkreśla, iż przedsiębiorczość ma kluczowe znaczenie dla rozwoju gospodarczego ${ }^{1}$. W literaturze przedmiotu można odnaleźć także pogląd, iż przedsiębiorczość przyczynia się do powstawania nowych technologii, produktów oraz usług, a tym samym staje się jedną z determinant rozwoju cywilizacyjnego ${ }^{2}$.

Przedsiębiorczość i bycie przedsiębiorczym łączone są ze swego rodzaju aktywnością, pomysłowością, wykazywaniem inicjatywy, zaradnością, szybkością podejmowania właściwych reakcji oraz decyzji, umiejętnością przystosowania się do zmieniających się warunków, czy też skomplikowanych sytuacji, a także zdolnością do podejmowania ryzyka. Interpretacja leksykalna słów „przedsiębiorczość” i ,przedsiębiorczy” ujmuje je w postaci posiadania ducha inicjatywy, a także zdolności, pomysłowości, zaradności do podejmowania różnych spraw, zwłaszcza w dziedzinie przemysłu i handlu ${ }^{3}$.

\footnotetext{
* Dr inż., Politechnika Częstochowska, Wydział Zarządzania.

${ }^{1}$ M. B ratnicki, Przedsiębiorczość, konkurencyjność $i$ dtugowieczność organizacji, [w:] B. Godziszewski, M. Haffer, M .J. St ankiewicz (red.), Przedsiębiorstwo na przełomie wieków, Wydawnictwo UMK, Toruń 2001, s. 244.

${ }^{2}$ Por. m. in.: R. B. Mellor, G. Coulton, A. Chick, A. Bifulco, N. Mellor, A. Fi s h e r, Przedsiębiorczość, PWE, Warszawa 2011, s. 17; T. Lis, W. Ig ras, Informatyczne wspomaganie procesów informacyjnych, a optymalizacja zarzqdzania przedsiębiorstwem, [w:] Z. S z y je w ski, J. S. Now a k, J. Grabar a (red.), Strategie informatyzacji, PTI - Oddział Górnośląski, Katowice 2006, s. 58-59.

${ }^{3}$ Stownik języka polskiego, Wydawnictwo Naukowe PWN, Warszawa 1979, s. 968.
} 
Należy podkreślić, iż powyżej wymienione zdolności postępowania mają zazwyczaj swoje odzwierciedlenie w obszarze ekonomicznym. Przytaczając słowa P. F. Druckera można wskazać, iż przedsiębiorczość nie ogranicza się do sfery gospodarczej, ale z niej się wywodzi ${ }^{4}$. Działania przedsiębiorcze można podejmować w wielu dziedzinach życia i w wielu sytuacjach. Problematyka przedsiębiorczości znajduje swój wyraz zarówno w życiu gospodarczym, jak i społecznym. Taki stan należy tłumaczyć różnorodnością ludzkich charakterów i osobowości oraz motywów postępowania i działania mających swoje odzwierciedlenie w zagadnieniu przedsiębiorczości.

W literaturze przedmiotu można odnaleźć różnorodne próby wyjaśnień pojęcia przedsiębiorczości, wskazujące na złożoność i wielowymiarowość jego istoty. J. Duraj i M. Papiernik-Wojdera zaznaczają, iż przedsiębiorczość jest zjawiskiem interdyscyplinarnego oglądu, a formułowanie jego określenia stwarza konieczność zawarcia kompromisu przez przedstawicieli różnorodnych dziedzin naukowych ${ }^{5}$. Cytowani powyżej autorzy zauważają również, iż próby definiowania przedsiębiorczości sprowadzają się zazwyczaj do eksponowania jej ekonomicznego wymiaru. Ma to swoje uzasadnienie w traktowaniu przedsiębiorczości jako jednego z czynników produkcji pozwalającego na bardziej efektywne działania danej jednostki ${ }^{6}$. Tym samym szersza interpretacja tego terminu wymaga uwzględnienia zarówno spojrzenia przez pryzmat ekonomii, ale także innych obszarów naukowych.

\section{ISTOTA PRZEDSIĘBIORCZOŚCI W WYMIARZE EKONOMICZNYM}

Rozpatrywanie problematyki przedsiębiorczości z punktu widzenia działań ekonomicznych pozwala zauważyć wielość ujęć definicyjnych obrazujących jej różnorodne perspektywy. S. Sudoł identyfikuje przedsiębiorczość jako cechę, przez którą należy rozumieć gotowość oraz zdolność do podejmowania i rozwiązywania nowych problemów, mając jednocześnie świadomość związanego z tym ryzyka, a także posiadając umiejętność wykorzystywania pojawiających się szans i okazji oraz dysponując zdolnością szybkiego i elastycznego przystosowywania się do zmieniających się warunków panujących w otoczeniu ${ }^{7}$. P. F. Drucker zaznacza jednakże, iż przedsiębiorczość nie należy do cech wrodzonych danej osoby, ale dana osoba może tę cechę nabyć, nauczyć się jej i staje

\footnotetext{
${ }^{4}$ P. F. Dru c ker, Innowacje i przedsiębiorczość. Praktyka i zasady, PWE, Warszawa 1992, s. 36 .

5 J. Duraj, M. Papiernik-Wojdera, Przedsiębiorczość i innowacyjność, Difin, Warszawa 2010, s. 19.

${ }^{6}$ Ibidem, s. 21.

${ }^{7}$ B. Godziszewski, M. Haffer, M. J. Stankiewicz, S. Sudoł, Przedsiębiorstwo. Teoria i praktyka zarzqdzania, PWE, Warszawa 2011, s. 29.
} 
się ona tym samym sposobem zachowania, aniżeli cechą osobowości ${ }^{8}$. Należy wskazać zatem, iż przedsiębiorczość jest utożsamiana z przymiotem danej osoby, sposobem jej działania oraz nastawieniem do wykonywanej pracy. B. Nogalski zauważa ponadto, że cechy charakteru, chęć do działania, kreatywność i pomysłowość, to wewnętrzne uwarunkowania przedsiębiorczości należące do podmiotowych predyspozycji przedsiębiorcy. Niemniej jednak występowanie zachowań przedsiębiorczych uwarunkowane jest także czynnikami zewnętrznymi, znajdującymi się w otoczeniu przedsiębiorcy, do których w głównej mierze należy zaliczyć: sytuację na rynku, siłę roboczą, konkurencję, poziom dostępnego kapitału oraz uwarunkowania formalne, prawne, polityczne i społeczno-kulturowe9.

Przyjmując natomiast interpretację R. W. Griffina można rozpatrywać zagadnienie przedsiębiorczości, jako proces organizowania i prowadzenia działalności gospodarczej, a także podejmowania związanego z nią ryzyka ${ }^{10}$. Powstanie i rozwój tego procesu stanowi rezultat rozmaitych uwarunkowań, uzależnionych zarówno od wewnętrznych predyspozycji danych osób, jak też od warunków zewnętrznych, które wyznaczają tempo rozwoju nowoutworzonych podmiotów gospodarczych. ${ }^{11}$ J. Duraj i M. Papiernik-Wojdera wskazują, iż to ujęcie przedsiębiorczości jest nakierowane na dość wąski cel, łączący się z zarządczą perspektywą założenia oraz prowadzenia własnego przedsiębiorstwa ${ }^{12}$. W tym wymiarze przedsiębiorczość jest zatem utożsamiana z działaniami odnoszącymi się do zawiązywania i kierowania danym podmiotem gospodarczym.

W szerszym ujęciu, wykraczającym poza tematykę przedsiębiorstwa, można rozpatrywać istotę przedsiębiorczości w życiu gospodarczym danego kraju. W tym odniesieniu przedsiębiorczość identyfikowana jest z twórczym rozpoznawaniem oraz analizowaniem możliwości wykorzystania strategii konkurowania i powinna być traktowana jako jeden z najcenniejszych zasobów współczesnych społeczeństw ${ }^{13}$. Podobne ujęcie problematyki przedsiębiorczości można odnaleźć w stanowisku Ministerstwa Gospodarki sugerującym uznanie przedsiębiorczości za główny czynnik rozwoju społeczno-gospodarczego oraz kluczowy warunek osiągnięcia konkurencyjności gospodarki danego kraju, rozu-

\footnotetext{
${ }^{8}$ P. F. Drucker, op. cit., s. 34.

${ }^{9}$ B. Nogalski, Przedsiębiorczość - wspótczesnym wyzwaniem polskiej gospodarki, [w:] Przedsiębiorstwo - Przedsiębiorczość - Rynek, Wydawnictwo SGH, Warszawa 2003, s. 159.

10 Por. R. W. Griffin, Podstawy zarzqdzania organizacjami, Wydawnictwo Naukowe PWN, Warszawa 1996, s. 730.

11 J. Moczydłowska, I. Pacewicz, Przedsiębiorczość, Wydawnictwo Oświatowe FOSZE, Rzeszów 2007, s. 29.

${ }_{12}^{12}$ J. Duraj, M. Papiernik-Wojdera,op. cit., s. 20.

${ }^{13}$ Por. m. in.: W. Jan as z (red.), Innowacje $w$ rozwoju przedsiębiorczości $w$ procesie transformacji, Difin, Warszawa 2004, s. 10; P. Ku rás, Genesis and Basic Assumptions of the Resource-based View in the Strategic Management of an Enterprise, [w:] I. O tol a (red.), Determinants of Modern Management Concepts in the Enterprises. Resources - Strategies - Decisions, Vysoka Skola Banska - Technicka Iniverzita Ostrava, Ostrava 2013, s. 81-92.
} 
mianej jako długookresowa zdolność do sprostania konkurencji zewnętrznej (na rynku krajowym, unijnym i krajów trzecich) ${ }^{14}$.

Istotność zagadnienia przedsiębiorczości została także podkreślona w Traktacie Ustanawiającym Wspólnotę Europejską. Zgodnie z postanowieniami zawartymi w tym dokumencie w krajach członkowskich UE zakazane jest ograniczenie swobody przedsiębiorczości obywateli jednego Państwa Członkowskiego na terytorium innego Państwa Członkowskiego. Pojęcie swobody przedsiębiorczości jest w tym przypadku rozumiane głównie jako podejmowanie i wykonywanie działalności prowadzonej na własny rachunek, jak również zakładanie i zarządzanie przedsiębiorstwami ${ }^{15}$.

Powyższe rozważania pozwalają zauważyć wielowymiarowość zagadnienia przedsiębiorczości. $Z$ jednej strony jego waga i znaczenie wyraża się w wymiarze mikroekonomicznym, łączącym się $\mathrm{z}$ chęcią podjęcia ryzyka założenia i prowadzenia własnej działalności gospodarczej, a przez to przejęcia odpowiedzialności za samozatrudnienie i zatrudnienie, w założonym przez siebie przedsiębiorstwie, innych osób oraz przejęcia odpowiedzialności za wszelkie aspekty organizacyjne łączące się z funkcjonowaniem tego przedsiębiorstwa. $\mathrm{Z}$ drugiej strony przedsiębiorczość jest interpretowana jako zjawisko o szerokim spektrum oddziaływania na sferę rynkową i może być traktowana jako metoda tworzenia nowych miejsc pracy oraz sposób redukowania bezrobocia, przyczyniając się dzięki temu do dalszego rozwoju gospodarczego danego kraju. Niemniej jednak należy pamiętać, iż wymiar ekonomiczny przedsiębiorczości jest zintegrowany z jej wymiarem społecznym.

\section{ANALIZA EMPIRYCZNA WYBRANYCH ASPEKTÓW PRZEDSIĘBIORCZOŚCI}

Badania empiryczne mające na celu ocenę przedsiębiorczości w Polsce i porównanie tych nastawień do analogicznych stanowisk w wybranych krajach europejskich zostało przeprowadzone na podstawie danych opublikowanych przez Polską Agencję Rozwoju Przedsiębiorczości, przeprowadzonych w ramach badania Global Entrepreneurship Monitor $(\mathrm{GEM})^{16}$. W analizie uwzględ-

\footnotetext{
${ }^{14}$ www.mg.gov.pl/wspieranie_przedsiębiorczości.

15 Por.: Art. 43 Traktatu Ustanawiajacego Wspólnote Europejska, http://oide.sejm.gov.pl /oide /index.php?option=com_content\&view=article\&id=14436\&Itemid=436\#3.III. 2 .

${ }^{16}$ GEM jest największym projektem badawczym w zakresie przedsiębiorczości. W 2012 r. badaniami objęto 69 krajów, które skupiają 74\% populacji świata i 87\% światowego produktu brutto. Próba badawcza liczyła 198 tys. respondentów. Badania w projekcie GEM prowadzone są w dwóch częściach. Pierwsza z nich to typowo ilościowe badanie populacji dorosłych (ang. adult population survey - APS) przeprowadzane na próbie osób w wieku produkcyjnym. Druga część badań - jakościowa - polega na zbieraniu opinii ekspertów krajowych (ang. national experts survey - NES). Badanie APS populacji dorosłych przeprowadza się na próbie co najmniej 2000
} 
niono następujące wymiary przedsiębiorczości: postawy i percepcję przedsiębiorczości oraz motywy zakładania działalności gospodarczej.

W zakresie postaw danej jednostki, charakteryzujących przedsiębiorczość, zostały wyróżnione kategorie związane inicjatywą podjęcia działalności gospodarczej (określone w badaniu jako intencje przedsiębiorcze ${ }^{17}$ ) oraz dostrzeganiem, przez podmioty poddane badaniu, korzystnych warunków do rozpoczęcia działalności gospodarczej (określone $\mathrm{w}$ badaniu jako rozpoznawanie szansy biznesowej). Wśród postaw przedsiębiorczych zidentyfikowano także kategorie odnoszące się do autoweryfikacji posiadanych umiejętności i wiedzy w zakresie posiadanych zdolności niezbędnych do wykorzystywania szans pojawiających się podczas prowadzenia działalności gospodarczej (określonych w badaniu jako zdolności przedsiębiorcze). Jako ostatnią kategorię, odnoszącą się do postaw charakteryzujących przedsiębiorczość, określono istotny czynnik ograniczający poziom działań przedsiębiorczych, za jaki przyjęto strach przed niepowodzeniem.

W tab. 1 przedstawiono dane procentowe obrazujące odsetek ankietowanych deklarujących przyjęcie wymienionych powyżej postaw przedsiębiorczych.

Posiadanie intencji przedsiębiorczych polegających na inicjatywie założenia działalności gospodarczej jest znacząco różne w analizowanych krajach. W roku 2011 najmniejszą chęć w tym zakresie wykazywali ankietowani w Rosji i Niemczech, a największą w Rumunii oraz na Łotwie. Natomiast w roku 2012 do liderów w zakresie intencji przedsiębiorczych także należały Rumunia i Łotwa, do których dołączyła Macedonia, a najmniejszy poziom zamiaru założenia działalności gospodarczej odnotowano w Norwegii i wciąż w Rosji. Polska z wynikiem 26,94\% w roku 2011 i 24,2\% w roku 2012 znajdowała się odpowiednio na trzecim i piątym miejscu w gronie badanych podmiotów. Należy zatem wskazać na spadek intencji przedsiębiorczych wśród Polaków. Nie można jednakże wyznaczyć wyraźnej tendencji spadkowej, czy też wzrostowej intencji przedsiębiorczych charakterystycznej dla badanych krajów. W czternastu państwach nastąpił ich wzrost, a w trzynastu uległy one zmniejszeniu.

osób w każdym kraju biorącym udział w projekcie. Badanie zazwyczaj przeprowadza się metodą Computer Assisted Telephone Interview (CATI) z uwzględnieniem wykorzystania przez gospodarstwa domowe w każdym kraju telefonii stacjonarnej oraz komórkowej. Natomiast badanie ekspertów krajowych NES dokonywane jest na próbie co najmniej 36 specjalistów z różnych dziedzin powiązanych bezpośrednio lub pośrednio z przedsiębiorczością. Celem tej części badania jest rozpoznanie ramowych czynników przedsiębiorczości w danym kraju. W każdym kraju wyboru grupy ekspertów dokonuje się w oparciu o te same kryteria, z których głównymi są rodzaj prowadzonej działalności (naukowiec, menedżer, polityk, itd.) oraz doświadczenie w prowadzeniu działalności przedsiębiorczej (przedsiębiorca - nieprzedsiębiorca). Zob. Raport z badania Global Entrepreneurship Monitor - Polska 2012, Polska Agencja Rozwoju Przedsiębiorczości, Warszawa 2013, www.parp.gov.pl.

${ }^{17}$ Intencje przedsiębiorcze zostały zmierzone jako odsetek osób w wieku 18-64 lata, które w najbliższych trzech latach wyrażają zamiar założenia działalności gospodarczej. Zob. Raport z badania..., op. cit., s. 14. 
Tabela 1

Postawy przedsiębiorcze w wybranych krajach europejskich i w USA (\% badanych podmiotów)

\begin{tabular}{|c|c|c|c|c|c|c|c|c|}
\hline \multirow[t]{2}{*}{ Kraj } & \multicolumn{2}{|c|}{$\begin{array}{c}\text { Intencje } \\
\text { przedsiębiorcze }\end{array}$} & \multicolumn{2}{|c|}{$\begin{array}{c}\text { Rozpoznawanie } \\
\text { szansy }\end{array}$} & \multicolumn{2}{|c|}{$\begin{array}{c}\text { Zdolności } \\
\text { przedsiębiorcze }\end{array}$} & \multicolumn{2}{|c|}{$\begin{array}{c}\text { Strach przed } \\
\text { niepowodzeniem }\end{array}$} \\
\hline & 2011 & 2012 & 2011 & 2012 & 2011 & 2012 & 2011 & 2012 \\
\hline Austria & 14,52 & 11,6 & 47,83 & 49,2 & 47,42 & 49,6 & 43,75 & 43,5 \\
\hline Belgia & 11,98 & 10,7 & 42,97 & 33,3 & 43,99 & 37,1 & 41,96 & 45,7 \\
\hline \begin{tabular}{|l|} 
Bośnia \\
i Hercegowina
\end{tabular} & 21,56 & 24,9 & 20,53 & 19,6 & 48,86 & 49,1 & 37,70 & 39,1 \\
\hline Chorwacja & 21,64 & 23,6 & 18,25 & 17,2 & 48,97 & 44,1 & 45,72 & 46,3 \\
\hline Dania & 8,90 & 8,4 & 46,64 & 44,4 & 34,97 & 31,0 & 41,97 & 42,1 \\
\hline Estonia & b.d. & 20,1 & b.d. & 45,2 & b.d. & 43,2 & b.d. & 44,3 \\
\hline Finlandia & 8,05 & 9,4 & 60,82 & 55,3 & 37,26 & 34,3 & 35,58 & 39,3 \\
\hline Francja & 19,76 & 18,9 & 34,92 & 37,5 & 38,43 & 35,7 & 43,80 & 46,7 \\
\hline Grecja & 12,29 & 10,5 & 10,87 & 13,0 & 49,69 & 50,0 & 67,59 & 72,4 \\
\hline Hiszpania & 9,66 & 12,1 & 14,41 & 13,9 & 50,86 & 50,4 & 51,78 & 51,6 \\
\hline Holandia & 9,76 & 10,1 & 47,78 & 34,4 & 41,87 & 42,3 & 36,64 & 39,2 \\
\hline Irlandia & 8,45 & 8,0 & 25,57 & 25,6 & 45,50 & 45,2 & 41,23 & 41,2 \\
\hline Litwa & 20,56 & 19,4 & 23,20 & 30,0 & 35,40 & 39,8 & 48,24 & 45,6 \\
\hline Łotwa & 27,99 & 26,9 & 23,65 & 33,1 & 46,53 & 43,6 & 44,74 & 38,1 \\
\hline Macedonia & b.d. & 29,1 & b.d. & 30,8 & b.d. & 55,1 & b.d. & 44,9 \\
\hline Niemcy & 7,60 & 8,9 & 35,17 & 36,2 & 37,14 & 37,1 & 49,92 & 49,0 \\
\hline Norwegia & 10,87 & 6,7 & 67,07 & 64,4 & 33,24 & 34,4 & 38,20 & 35,6 \\
\hline Polska & 26,94 & 24,2 & 33,10 & 20,4 & 51,99 & 53,9 & 54,05 & 58,7 \\
\hline Portugalia & 14,89 & 16,2 & 16,74 & 16,2 & 46,67 & 46,8 & 49,37 & 52,5 \\
\hline Rosja & 6,18 & 3,8 & 27,06 & 20,1 & 33,20 & 23,5 & 46,41 & 42,8 \\
\hline Rumunia & 27,71 & 30,8 & 36,06 & 36,7 & 41,63 & 38,3 & 43,05 & 45,1 \\
\hline Słowacja & 24,43 & 15,6 & 23,08 & 17,8 & 52,92 & 49,7 & 44,76 & 48,0 \\
\hline Słowenia & 10,03 & 14,7 & 18,37 & 19,6 & 50,79 & 51,3 & 39,30 & 41,5 \\
\hline Szwajcaria & 10,26 & 8,3 & 47,40 & 35,7 & 42,45 & 37,3 & 35,13 & 32,2 \\
\hline Szwecja & 10,42 & 11,7 & 71,49 & 66,5 & 40,32 & 37,0 & 37,05 & 38,9 \\
\hline Turcja & 11,32 & 18,8 & 32,36 & 39,9 & 42,08 & 49,4 & 26,51 & 35,5 \\
\hline USA & 15,77 & 16,5 & 36,25 & 43,5 & 55,69 & 55,9 & 37,14 & 37,8 \\
\hline Węgry & 21,90 & 15,3 & 14,22 & 11,0 & 39,98 & 39,8 & 44,54 & 45,9 \\
\hline $\begin{array}{l}\text { Wielka } \\
\text { Brytania }\end{array}$ & 10,37 & 11,5 & 33,30 & 32,8 & 42,47 & 47,1 & 45,75 & 40,9 \\
\hline Włochy & b.d. & 11,8 & b.d. & 19,8 & b.d. & 30,0 & b.d. & 56,6 \\
\hline
\end{tabular}

Źródło: opracowanie własne na podstawie: Raport z badania Global Entrepreneurship Monitor - Polska 2012, Polska Agencja Rozwoju Przedsiębiorczości, Warszawa 2013, s. 13 i 14 oraz Raport z badania Global Entrepreneurship Monitor - Polska 2011, Polska Agencja Rozwoju Przedsiębiorczości, Warszawa 2012, s. 16 i 17. 
Kolejną kategorią, łączącą się z postawami przedsiębiorczymi, jest dostrzeganie szansy biznesowej mierzone przez odsetek osób uważających, iż w ich otoczeniu panują korzystne warunki do rozpoczęcia działalności gospodarczej. Najbardziej optymistyczne pod tym względem jest społeczeństwo krajów skandynawskich. W Szwecji, Norwegii i Finlandii odsetek osób rozpoznających szansę biznesową kształtuje się, w pierwszym analizowanym roku, w przedziale od ponad $60 \%$ do blisko $72 \%$. Niemniej jednak należy wskazać na pewną tendencję spadkową w tym zakresie na przestrzeni badanego okresu. Wśród polskich ankietowanych także zmniejszyła się liczba osób rozpoznających szansę biznesową. O ile w roku 2011 wartość omawianego wskaźnika wyniosła 33,1\%, to $\mathrm{w}$ roku następnym jego poziom wyraźnie spadł osiagając wartość 20,4\%. Niemniej jednak najbardziej pesymistyczne nastawienie w zakresie dostrzegania szansy biznesowej panuje na Węgrzech oraz w Grecji.

Należy podkreślić, iż badane jednostki stosunkowo wysoko oceniają własne zdolności w zakresie umiejętności i wiedzy niezbędnej do prowadzenia działalności gospodarczej. We wszystkich omawianych krajach co najmniej $30 \%$ ankietowanych deklaruje wysoką samoocenę w tym zakresie. Najmniejszą wiarę W swoje możliwości biznesowe deklarują Norwegowie (rok 2011), Rosjanie (rok 2011 i 2012) oraz Duńczycy (rok 2012). Największy poziom samooceny w tym zakresie występuje w Stanach Zjednoczonych (ponad 55\% w obu analizowanych latach). Niemniej jednak Polacy także oceniają wysoko własną wiedzę i umiejętności biznesowe. Ich posiadanie zadeklarowało blisko 52\% w roku 2011 i 54\% w roku 2012 ankietowanych w Polsce.

Ostatnim wyróżnionym czynnikiem odnoszącym się do postaw przedsiębiorczych jest strach przed porażką, który można uznać za ogranicznik działań przedsiębiorczych. W analizowanym okresie stosunkowo wysoki procent wszystkich ankietowanych deklaruje taką obawę. Największa jest ona jednak wśród Greków, Polaków i Hiszpanów. W tych krajach ponad 50\% badanych podmiotów zaniechałoby rozpoczęcia działalności gospodarczej w obawie przed niepowodzeniem. Należy zatem podkreślić, iż w Polsce strach przed porażką utrzymuje się na skrajnie wysokim poziomie.

Następnym analizowanym wymiarem przedsiębiorczości jest jej percepcja przez ankietowane podmioty. W badaniu GEM wyznaczone zostały cztery charakterystyczne czynniki identyfikowane z postrzeganiem i odbieraniem przedsiębiorczości. Wskazują one na uznanie przedsiębiorczości za dobrą ścieżkę kariery, a także przypisują przedsiębiorcom wysoki status społeczny. Za istotny czynnik percepcji przedsiębiorczości uznano także przekazy medialne tworzące pozytywny jej obraz. W tab. 2 przedstawiono wartości procentowe wskazujące na postrzeganie przedsiębiorczości przez jednostki poddane badaniu. 
Tabela 2

Percepcja przedsiębiorczości w wybranych krajach europejskich i w USA

(\% badanych podmiotów)

\begin{tabular}{|c|c|c|c|c|c|c|}
\hline \multirow[t]{2}{*}{ Kraj } & \multicolumn{2}{|c|}{$\begin{array}{l}\text { Przedsiębiorczość jako } \\
\text { dobra ścieżka kariery }\end{array}$} & \multicolumn{2}{|c|}{$\begin{array}{l}\text { Wysoki status } \\
\text { przedsiębiorczości }\end{array}$} & \multicolumn{2}{|c|}{$\begin{array}{c}\text { Przedsiębiorczość } \\
\text { w mediach }\end{array}$} \\
\hline & 2011 & 2012 & 2011 & 2012 & 2011 & 2012 \\
\hline Austria & 53,96 & $4 \quad 46,4$ & 67,73 & 75,8 & 699,51 & b.d. \\
\hline Belgia & 63,61 & 62,3 & 54,76 & 57,4 & 47,17 & 53,8 \\
\hline $\begin{array}{l}\text { Bośnia } \\
\text { i Hercegowina }\end{array}$ & 82,17 & 80,9 & 71,02 & 72,3 & 42,73 & 39,4 \\
\hline Chorwacja & 65,33 & 64,2 & 46,95 & 41,7 & 40,9 & 39,7 \\
\hline Dania & b.d. & b.d. & b.d. & b.d. & b.d. & b.d. \\
\hline Estonia & b.d. & 54,8 & b.d. & 62,5 & b.d. & 41,5 \\
\hline Finlandia & 45,53 & 45,1 & 83,0 & 83,4 & 67,37 & 68,4 \\
\hline Francja & 65,76 & 64,5 & 67,95 & 76,8 & 46,92 & 41,1 \\
\hline Grecja & 61,0 & 64,4 & 69,08 & 68,3 & 32,49 & 33,1 \\
\hline Hiszpania & 65,15 & 63,6 & 66,49 & 63,7 & 44,58 & 47,3 \\
\hline Holandia & 83,37 & 79,3 & 67,19 & 65,2 & 62,16 & 58,3 \\
\hline Irlandia & 45,94 & 45,4 & 82,71 & 81,4 & 56,42 & 61,5 \\
\hline Litwa & b.d. & 63,1 & b.d. & 52,9 & b.d. & 37,3 \\
\hline Łotwa & b.d. & 59,7 & b.d. & 53,3 & b.d. & 53,3 \\
\hline Macedonia & b.d. & 69,9 & b.d. & 66,7 & b.d. & 64,1 \\
\hline Niemcy & 55,02 & 48,9 & 78,35 & 76,4 & 49,74 & 49,0 \\
\hline Norwegia & 52,89 & 50,4 & 80,42 & 79,5 & 60,24 & 59,3 \\
\hline Polska & 72,87 & 67,9 & 64,44 & 57,1 & 57,97 & 56,3 \\
\hline Portugalia & b.d. & b.d. & b.d. & b.d. & b.d. & b.d. \\
\hline Rosja & 64,54 & 59,8 & 65,25 & 63,1 & 55,32 & 44,7 \\
\hline Rumunia & 67,85 & 71,2 & 69,42 & 73,6 & 56,74 & 55,2 \\
\hline Słowacja & 54,55 & 50,3 & 64,43 & 74,4 & 55,11 & 59,4 \\
\hline Słowenia & 53,71 & 52,7 & 69,73 & 71,1 & 45,10 & 51,1 \\
\hline Szwajcaria & b.d. & 44,2 & b.d. & 63,5 & b.d. & 57,4 \\
\hline Szwecja & 51,78 & b.d. & 70,82 & b.d. & 62,33 & b.d. \\
\hline Turcja & b.d. & 67,1 & b.d. & 76,1 & b.d. & 57,5 \\
\hline USA & b.d. & b.d. & b.d. & b.d. & b.d. & b.d. \\
\hline Węgry & 53,75 & 41,5 & 78,23 & 74,0 & 33,76 & 29,3 \\
\hline $\begin{array}{l}\text { Wielka } \\
\text { Brytania }\end{array}$ & 51,94 & 49,8 & 81,0 & 76,7 & 47,30 & 47,0 \\
\hline Włochy & b.d. & 66,7 & b.d. & 69,7 & b.d. & 51,3 \\
\hline
\end{tabular}

Źródło: opracowanie własne na podstawie: Raport z badania Global Entrepreneurship Monitor - Polska 2012, op. cit., s. 15 oraz Raport z badania Global Entrepreneurship Monitor - Polska 2011, op. cit., s. 18 i 19. 
Na podstawie danych zawartych w tab. 2 można wnioskować, iż jednostki poddane badaniu w bardzo dużej mierze uznają przedsiębiorczość za dobrą ścieżkę kariery. Opinię tę potwierdza co najmniej $40 \%$ ankietowanych podmiotów we wszystkich badanych krajach. Liderami pod tym względem są Bośnia i Hercegowina oraz Holandia, w których około $80 \%$ mieszkańców uznaje działania przedsiębiorcze za pomocne i niezbędne do zrobienia kariery. Niemniej jednak pomiędzy poszczególnymi państwami istnieją w tym zakresie dość duże rozpiętości punktów procentowych. Do krajów o największym pod tym względem sceptycyzmie należą Węgry, Irlandia oraz Finlandia. W Polce omawiany wskaźnik kształtował się na poziomie 72,87\% w roku 2011 i 67,9\% w roku 2012. Wśród Polaków zanotowany zatem został spadek percepcji przedsiębiorczości, jako dobrej ścieżki kariery. Podobna tendencja dotyczyła, z wyjątkiem Rumunii, wszystkich ankietowanych państw.

Następnym czynnikiem łączącym się z postrzeganiem i odbieraniem przedsiębiorczości jest przypisywanie przedsiębiorcom wysokiego statusu społecznego. Wśród podmiotów poddanych badaniu jest to dość powszechna opinia, wyrażana przez ponad 60\% wszystkich ankietowanych. Wyjątek stanowi Chorwacja, w której poziom omawianego wskaźnika oscyluje wokół 45\%. W Polsce wysoki status społeczny przypisuje przedsiębiorcom 64,44\% ankietowanych w roku 2011 i 57,1\% w roku 2012.

Wśród kryteriów percepcji przedsiębiorczości wyróżniony został także jej pozytywny obraz tworzony przez przekazy medialne. Najlepszy wizerunek przedsiębiorców w mediach został odnotowany w Finlandii, w której poziom omawianego wskaźnika zbliżył się do wartości 70\%. Natomiast najmniej korzystny wizerunek podmiotów prowadzących działalność gospodarczą jest przedstawiany w Grecji i na Węgrzech. W Polsce ponad 50\% ankietowanych osób uznaje pozytywny obraz przedsiębiorczości przedstawiany w przekazach medialnych.

Ostatnim z analizowanych wymiarów przedsiębiorczości jest identyfikacja motywu, jakim kierowali się przedsiębiorcy przy założeniu działalności gospodarczej. W przeprowadzonym badaniu ankietowym zidentyfikowane zostały dwa skrajne typy motywacji. Pierwszym z nich jest dążenie do wykorzystania szansy powiązane z podniesieniem swojego standardu życia poprzez możliwość wzrostu dochodu lub niezależności zawodowej. Natomiast drugi motyw łączy się koniecznością podejmowaną w obliczu niemożliwości znalezienia pożądanego zatrudnienia. W tab. 3 przedstawiono odsetek, wskazujących na omówione powyżej motywy podejmowania działalności gospodarczej.

Tabela 3 obrazuje dane przedstawiające poziom przedsiębiorczości opartej na szansie związanej z poprawą standardu życia oraz podejmowanej z konieczności. Na tej podstawie można stwierdzić, iż jedynie na Słowacji osoby zaangażowane we wszystkie stadia rozwoju aktywności przedsiębiorczej deklarują maksymalnie w 10,18\%, iż założyły swoje przedsiębiorstwa chcąc wykorzystać szansę związaną z poprawą standardu życia. W większości krajów taką deklarację złożyło około 5\% ankietowanych. 
Tabela 3

Motywy podejmowania działalności gospodarczej ${ }^{18} \mathrm{w}$ wybranych krajach europejskich i w USA (\% przedsiębiorców) $)^{19}$

\begin{tabular}{|c|c|c|c|c|}
\hline \multirow[t]{2}{*}{ Kraj } & \multicolumn{2}{|c|}{$\begin{array}{c}\text { Szansa związana z poprawą } \\
\text { standardu życia }\end{array}$} & \multicolumn{2}{|c|}{ Konieczność } \\
\hline & 2011 & 2012 & 2011 & 2012 \\
\hline Austria & 8,78 & 38,2 & 1,58 & 10,8 \\
\hline Belgia & 4,76 & 61,6 & 0,59 & 17,9 \\
\hline $\begin{array}{l}\text { Bośnia i Hercego- } \\
\text { wina }\end{array}$ & 3,05 & 20,1 & 4,97 & 58,3 \\
\hline Chorwacja & 4,61 & 35,7 & 2,59 & 34,2 \\
\hline Dania & 4,25 & 70,7 & 0,33 & 8,2 \\
\hline Estonia & b.d. & 49,1 & b.d & 18,2 \\
\hline Finlandia & 4,31 & 59,9 & 1,14 & 17,1 \\
\hline Francja & 4,83 & 58,9 & 0,85 & 18,1 \\
\hline Grecja & 5,87 & 32,1 & 2,02 & 29,9 \\
\hline Hiszpania & 4,16 & 32,5 & 1,50 & 25,6 \\
\hline Holandia & 6,98 & 66,4 & 0,75 & 8,4 \\
\hline Irlandia & 4,86 & 40,5 & 2,14 & 28,1 \\
\hline Litwa & 7,97 & 51,5 & 3,20 & 24,6 \\
\hline Łotwa & 8,43 & 46,0 & 3,07 & 25,3 \\
\hline Macedonia & b.d. & 28,7 & b.d. & 52,0 \\
\hline Niemcy & 4,15 & 50,7 & 1,04 & 21,7 \\
\hline Norwegia & 5,99 & 69,6 & 0,30 & 7,4 \\
\hline Polska & 4,55 & 30,1 & 4,30 & 40,7 \\
\hline Portugalia & 5,97 & 53,1 & 1,34 & 17,9 \\
\hline Rosja & 3,17 & 31,4 & 1,23 & 36,4 \\
\hline Rumunia & 5,68 & 37,7 & 4,09 & 24,2 \\
\hline Słowacja & 10,18 & 42,9 & 3,91 & 35,6 \\
\hline Słowenia & 2,96 & 64,0 & 0,44 & 7,4 \\
\hline Szwajcaria & 5,52 & 57,5 & 0,75 & 18,1 \\
\hline Szwecja & 5,13 & 48,6 & 0,35 & 6,8 \\
\hline Turcja & 7,57 & 54,6 & 3,75 & 30,9 \\
\hline USA & 9,07 & 59,5 & 2,62 & 21,4 \\
\hline Węgry & 4,05 & 35,3 & 1,95 & 31,1 \\
\hline Wielka Brytania & 5,80 & 42,6 & 1,25 & 18,3 \\
\hline Włochy & b.d. & 22,3 & b.d. & 15,7 \\
\hline
\end{tabular}

Źródło: opracowanie własne na podstawie: Raport z badania Global Entrepreneurship Monitor-Polska 2012, op. cit., s. 21 i 22 oraz Raport z badania Global Entrepreneurship Monitor-Polska 2011, op. cit., s. 28.

${ }^{18} \mathrm{~W}$ tabeli nie uwzględniono motywacji mieszanej.

${ }^{19} \mathrm{~W}$ badaniu dotyczącym roku 2011 przedstawiono odsetek osób ankietowanych znajdujących się we wszystkich stadiach rozwoju aktywności przedsiębiorczej (tzn. osoby zaangażowane w zakładanie działalności gospodarcze, nowych przedsiębiorców (prowadzących działalności do 42 miesięcy przed przeprowadzeniem badania), dojrzałych przedsiębiorców oraz osoby zamierzające zaprzestać prowadzenia działalności. Natomiast w badaniu dotyczącym roku 2012 przedstawiono odsetek osób, które są zaangażowane w zakładanie działalności gospodarczej lub prowadzenie nowego przedsiębiorstwa (do 42 miesięcy przed przeprowadzeniem badania). 
W Polsce poziom omawianego wskaźnika wyniósł 4,55\%. Podobnie niski odsetek wyróżnionych powyżej przedsiębiorców, we wszystkich ankietowanych krajach, wskazuje na przymus, jako motywację do założenia działalności gospodarczej. Wśród Polaków zaangażowanych we wszystkie stadia rozwoju aktywności przedsiębiorczej taką deklarację złożyło 4,3\% osób. Należy zatem przypuszczać, iż badane jednostki kierowały się innymi, nieuwzględnionymi w badaniu czynnikami motywującymi je do podjęcia działalności gospodarczej.

Wśród osób zaangażowanych w zakładanie działalności gospodarczej lub prowadzenie nowego przedsiębiorstwa deklarację szansy związanej z poprawą standardu życia w wyniku prowadzenia własnego przedsiębiorstwa złożyło 30\% badanych, w niemal wszystkich ankietowanych krajach. Wyjątkiem są Włochy i Macedonia, gdzie poziom omawianego miernika wyniósł odpowiednio 22,3\% i $28,7 \%$. Wśród polskich nowych przedsiębiorców także panuje sceptycyzm odnośnie wykorzystania szansy powiązanego z podniesieniem swojego standardu życia w wyniku podjęcia działalności gospodarczej. Dla naszego kraju poziom omawianego wskaźnika wyniósł 30,1\%. Natomiast jest to jeden z najistotniejszych czynników motywacyjnych dla Duńczyków, Norwegów oraz Holendrów. W tych krajach poziom omawianego wskaźnika przekroczył $66 \%$.

Należy podkreślić istotną rozbieżność wśród ankietowanych nowych przedsiębiorców, uznania przymusu jako motywu założenia działalności gospodarczej. Odsetek osób, które deklarują, iż z konieczności prowadzą własne nowopowstałe przedsiębiorstwo, waha się w badanych krajach od 6,8\% (Szwecja) do $58,3 \%$ (Bośnia i Hercegowina). W Polsce niniejszy pogląd wyraża równie wysoka ilość, bo 40,7\% ankietowanych nowych przedsiębiorców.

\section{ZAKOŃCZENIE}

Działania o charakterze przedsiębiorczym mogą wyrażać się we wszystkich dziedzinach funkcjonowania przedsiębiorstwa, łącząc się zarówno z szybkością we wprowadzaniu postępu techniczno-organizacyjnego, dynamicznością działań podejmowanych na rynku, zdolnością do wykorzystywania przez przedsiębiorstwo szans i okazji, czy też zdobywaniem przewagi konkurencyjnej. Pojęcie przedsiębiorczości interpretowane jest zarówno jako swoista własność i cecha, charakteryzująca daną osobę, ale także pojęcie to identyfikowane jest z procesem działań. Należy podkreślić, iż proces przedsiębiorczości jest procesem społecznym, który niejednokrotnie został uwarunkowany kulturowo i historycznie. Dlatego też obok różnic dotyczących danej jednostki, zasadną jest analiza powstałych w tym zakresie różnic między poszczególnymi krajami.

Empiryczna ocena postaw przedsiębiorczych pozwala wnioskować, iż pomimo dostrzegania szansy biznesowej i przeświadczenia, o dobrych warunkach do rozpoczęcia działalności gospodarczej, panujących w otoczeniu badanych 
podmiotów, ankietowani nie wykazują współmiernej chęci do założenia i prowadzenia działalności biznesowej. Podobnie znacznie więcej badanych podmiotów uważa, iż posiada odpowiednią wiedzę i umiejętności do prowadzenia działalności gospodarczej, a mimo to nie deklaruje chęci założenia tej działalności. Wytłumaczeniem takiego stanu może być obawa przed niepowodzeniem, którą wykazują się ankietowani. Pomimo rozpoznania szansy rynkowej oraz pozytywnej oceny własnych możliwości w zakresie prowadzenia działalności gospodarczej, niektóre z ankietowanych osób rezygnują z rozpoczęcia działań biznesowych w obawie przed niepowodzeniem.

Wśród zdecydowanej większości ankietowanych podmiotów, przedsiębiorczość jest łączona z dobrą możliwością osiagnięcia kariery zawodowej. Ponadto przedsiębiorcy postrzegani są jako osoby o wysokim statusie społecznym. Podkreślenia wymaga także dość duży odsetek przedsiębiorców, rozpoczynających swoją działalność gospodarczą lub będących we wczesnej jej fazie, wskazujących na szansę poprawy standardu życia oraz na przymus, jako istotne motywy podjęcia tej działalności. Pogłębionych badań wymagają jednakże dalsze czynniki, nieprzedstawione w prezentowanym badaniu, jakimi kierują się dane jednostki rozpoczynając swoją działalność gospodarczą.

\section{BIBLIOGRAFIA}

B ratni cki M., Przedsiębiorczość, konkurencyjność i dtugowieczność organizacji, [w:] B. Godziszewski, M. Haffer, M. J. Stankiewicz (red.) Przedsiębiorstwo na przełomie wieków, Wydawnictwo UMK, Toruń, 2001.

D r u c ker P. F., Innowacje i przedsiębiorczość. Praktyka i zasady, PWE, Warszawa 1992.

Duraj J., Papiernik-Wojdera M., Przedsiębiorczość $i$ innowacyjność, Difin, Warszawa 2010.

Godzis zew ski B., Haffer M., Stankiewicz M. J., Sudoł S., Przedsiębiorstwo. Teoria i praktyka zarzadzania, PWE, Warszawa 2011.

Griff in R. W., Podstawy zarzqdzania organizacjami, Wydawnictwo Naukowe PWN, Warszawa 1996.

Janasz W. (red.), Innowacje $w$ rozwoju przedsiębiorczości $w$ procesie transformacji, Difin, Warszawa 2004.

Ku r as P., Genesis and Basic Assumptions of the Resource-based View in the Strategic Management of an Enterprise, [w:] I. O to l a (red.), Determinants of Modern Management Concepts in the Enterprises. Resources - Strategies - Decisions, Vysoka Skola Banska - Technicka Iniverzita Ostrava, Ostrava 2013.

$\mathrm{Li}$ i $\mathrm{T}$., I g r a s W., Informatyczne wspomaganie procesów informacyjnych, a optymalizacja zarzqdzania przedsiębiorstwem, [w:] Z. S z yj e w ski, J. S. Now ak, J. Grab ara (red.), Strategie informatyzacji, PTI - Oddział Górnośląski, Katowice 2006.

Mellor R. B., Coulton G., Chick A., B ifulco A., Mellor N., Fisher A., Przedsiębiorczość, PWE, Warszawa 2011.

Moczydłowska J., Pacewicz I., Przedsiębiorczość, Wydawnictwo Oświatowe FOSZE, Rzeszów 2007. 
Nogalski B., Przedsiębiorczość - wspótczesnym wyzwaniem polskiej gospodarki, [w:] Przedsiębiorstwo - Przedsiębiorczość - Rynek, Wydawnictwo SGH, Warszawa 2003.

Raport z badania Global Entrepreneurship Monitor - Polska 2011, Polska Agencja Rozwoju

Przedsiębiorczości, Warszawa 2012, www.parp.gov.pl.

Raport z badania Global Entrepreneurship Monitor - Polska 2012, Polska Agencja Rozwoju

Przedsiębiorczości, Warszawa 2013, www.parp.gov.pl.

Stownik języka polskiego, Wydawnictwo Naukowe PWN, Warszawa 1979.

Traktat Ustanawiajacy Wspólnotę Europejska: http://oide.sejm.gov.pl/oide/index.php?option= com_content \&view=article\&id=14436\&Itemid=436\#3.III.2.

www.mg.gov.pl/wspieranie_przedsiębiorczości.

\section{Marlena Grabowska}

\section{ANALYSIS OF ESSENTIAL ASPECTS OF ENTREPRENEURSHIP IN POLAND AGAINST A BACKGROUND OF CHOSEN COUNTRIES}

The main goal of this paper is a theoretical and empirical analysis of selected aspects of entrepreneurship. The significance of this topic is mainly due to the role and impact of entrepreneurial activity on both the economic and social areas of the business units. Taking into consideration the variety and complexity of the entrepreneurship issues, its integral connection between economic sphere of activity and behavior, both individuals and society should be emphasized. In economic terms entrepreneurship is usually interpreted as the ability to solve business problems in creative and innovative way and its join also with the ability to use the opportunities and chances arising in business. Empirical studies aimed at to analyze and evaluate entrepreneurial attitudes have been carried out on the basis of data published by the Polish Agency for Enterprise Development, conducted as a part of the survey Global Entrepreneurship Monitor (GEM). Selected aspects of entrepreneurship in international perspective were analyzed. Particularly assessment of Poland relating to other countries were included.

Key words: entrepreneurship, entrepreneurial attitudes, perception of entrepreneurship, motives of entrepreneurial activities. 